Bytom

\title{
RELACJE POMIĘDZY METROPOLITĄ ANDRZEJEM SZEPTYCKIM A UKRAIŃSKĄ INTELIGENCJĄ
}

\section{Wstęp}

Metropolita Andrzej Szeptycki swoją posługę biskupią rozumiał jako realizację misji, którą Pan Jezus wyznaczył Piotrowi: „Paś baranki moje”. Podkreślał, że jego pierwszym zadaniem jest dbać o wieczne zbawienie swoich wiernych. Swoją duszpasterską opieką chciał objąć wszystkie warstwy ukraińskiego społeczeństwa. Zdawał sobie sprawę, że najtrudniejsza będzie praca nad formacją inteligencji. Jej przedstawicieli zapewniał o swej miłości i życzliwości. Starał się służyć im swoją pomocą i radą nie tylko w sprawach duchowych, ale także w społecznych i politycznych.

\section{Przesłanie Szeptyckiego do inteligencji}

Na przełomie XIX i XX wieku, gdy metropolita Andrzej Szeptycki rozpoczynał swą posługę, społeczeństwo ukraińskie w Małopolsce Wschodniej było niechętnie nastawione do kapłanów i Cerkwi greckokatolickiej. Wiara wśród wiernych była zachwiana i słaba. Działalność duchowieństwa prowadzona była przestarzałymi metodami i niewystarczająca, aby powstrzymać antycerkiewną agitację ${ }^{\mathrm{I}}$. Ogół ukraińskiej inteligencji był opanowany przez ideologie liberalizmu, radykalizmu i ateizmu. Pozostała część zachowywała się pasywnie i nie miała odwagi w zorganizowany sposób wystąpić i sprzeciwić się tym destrukcyjnym nurtom². Źródłem tego antyklerykalizmu byli przede wszystkim liderzy rodzącej się ukraińskiej świadomości narodowej. Największe zasługi na tym polu miał ukraiński poeta Taras Szewczenko. Nie oparł jednak odrodzenia narodowego na pozytywnych zasadach. Przy pomocy swojej poezji krzewił płytki liberalny nacjonalizm. Wyśmiewał Cerkiew greckokatolicką i drwił z Najświętszej Maryi Panny. Drugim pionierem błędnego ukraińskiego ruchu narodowego był Mychajło Dragomirow, ateista i anarchista. Trzecim antyklerykałem był Iwan Franko, propagator bezbożnej, materialistycznej filozofii. Nie może więc dziwić fakt, że wraz z przebudzeniem świadomości narodowej wśród Ukraińców zakorzeniły się i rozpowszechniły

\footnotetext{
* Ks. Adam Kubasik - zainteresowania naukowe koncentruje na historii Kościoła, a w szczególności na historii Cerkwi greckokatolickiej. E-mail: akubasik@poczta.onet.pl.

1 Н. Будка, Священикам і вірним Львівської Архієпархї, 1942, w: Письма-послання митрополита Андрея Шептицького з часів німецької окупації, ч. 2, wyd. М. Гринчишин, Yorkton, Sask 1969, s. 118.

2 Г. Хомишин, Українська Проблема, Станиславів 1933, s. 49.
} 
zasady wrogie wierze i religii: religijny liberalizm, radykalizm i ateizm. Prądy te wywarły duży wpływ na postawę ukraińskiej inteligencji³. Dlatego metropolita Andrzej Szeptycki, obejmując posługę biskupią, zdawał sobie sprawę, że praca z tą warstwą społeczeństwa będzie trudniejsza niż z pozostałymi. Grupa ta bowiem była najbardziej podatna na wpływy pogańskiego indyferentyzmu ${ }^{4}$. Wielu spośród przedstawicieli ukraińskiej inteligencji było religijnymi analfabetami. Nie znali podstawowych prawd katechizmu. Nie rozumieli istoty posłannictwa Cerkwi ${ }^{5}$. Przejawiało się to między innymi w ich sposobie dążenia do jedności narodowej. Według nich mniejszość, czyli Ukraińcy-grekokatolicy, powinni przyłączyć się do większości i przejść do Cerkwi prawosławnej. Uważali, że większość obywateli ma prawo decydować, do jakiej Cerkwi będzie należeć naród ukraiński. Zupełnie nieistotne było natomiast dla nich, jaka wiara czy Cerkiew zgodne są z Chrystusowym nauczaniem.

Szeptycki tłumaczył więc, że posłannictwem Cerkwi jest zbawienie ludzkości. Dlatego tylko jedna Cerkiew jest prawdziwa. Niezgodne z prawdą wiary jest przekonanie, że wszystko jedno, do jakiej Cerkwi się należy, ponieważ w każdej można osiągnąć zbawienie. Metropolita przestrzegał, że katolik głoszący tego typu poglądy jest bardziej oddalony od prawdziwej wiary niż prawosławny, który Cerkiew greckokatolicką uważa za heretycką, a prawosławną za prawdziwą ${ }^{6}$.

Greckokatolicki hierarcha ubolewał, że duża część ukraińskiej inteligencji, mimo oficjalnie deklarowanej wiary, nie przestrzegała w życiu codziennym przykazań Bożych i cerkiewnych. Przypominał jej więc, że chrześcijaństwo to nie tylko teoretyczna doktryna, ale również praktyka życia. Wzywał ją, aby swoją postawą dała świadectwo, że jest prawdziwie katolicka, a uczestnictwo w niedzielnej Eucharystii uważała za swój święty obowiązek. Prosił, by swoje dzieci uczyła katechizmu i modlitwy, wychowując je w ten sposób na dobrych chrześcijan?.

Szeptycki chwalił tych przedstawicieli nauki i kultury, którzy postępowali zgodnie z przykazaniami Bożymi, dając w ten sposób przykład chrześcijańskiego życia. Tych, którzy gorliwym życiem sakramentalnym zachęcali mniej oświeconych ludzi do pogłębionego życia duchowego, uważał za chlubę Cerkwi ${ }^{8}$. Jednak wierzących i praktykujących wśród inteligencji było niewielu. Większość spośród z tych, którzy przyznawali się do jedności z Cerkwią, katolikami była jedynie z nazwy. Nie znali oni elementarnych prawd katechizmu. Sumienia mieli zbrukane, ponieważ nie przystępowali do sakramentu pokuty ${ }^{9}$.

Największy ból sprawiali Szeptyckiemu ci, którzy przez brak rozwagi, lekkomyślność i pychę odpadli całkowicie od Cerkwi. Odrzucili Bożą naukę mimo, że nie zdołali jej poznać. Wyrzekli się wiary, ponieważ swe chrześcijańskie przekonania oparli na niedojrzałym

Tamże, s. 14-16.

4 Нама програма. Пастирськийлист до духовенства станиславівської єпрхії, 1899, w: Твори Слуги Божсого Митрополита Андрея Шептицького - пастирські листи (2 VIII 1899 р. - 7 IX 1901 р.), wyd. А. Базилевич, Toronto 1965, s. 26.

5 Г. Хомишин, dz.cyt., s. 49.

63 декретів собору 1942 р. Про виховання, 24 Х 1942, w: Письма..., s. 249-251.

7 Перше слово пастиря. (Пастирський лист до вірних Станиславівської Спархї, 1899 р.), w: Твори Слуги..., s. 16.

8 Tamże, s. 15.

9 Г. Хомишин, dz.cyt., s. 49. 
osądzie studenta, który jawił się jako opinia naukowca ${ }^{\mathrm{Io}}$. Władyka tłumaczył, że ludzie, którzy odrzucają chrześcijaństwo, najczęściej kierują się bardzo płytkimi i subiektywnymi argumentami. Wiarę, którą poznali w dzieciństwie, w wieku dojrzałym często przyjmują tak samo jak w czasach szkolnej nauki. Zamiast pogłębić ją indywidualnymi studiami, odrzucają ją, bo wydaje im się dziecinna, dobra jedynie dla ludzi niewykształconych. Szeptycki przekonywał, że gdyby wraz z wiekiem pogłębiali wiarę z dziecinnych lat, łatwo spostrzegliby, że pomiędzy wiarą a nauką nie ma sprzeczności. Może istnieć - przekonywał władyka - jedynie w przypadku wiary niepewnej i naiwnej, jaką ma człowiek umysłowo nierozwinięty. Tylko człowiek pozbawiony rozumu odrzuca Chrystusową naukę bez pełnego poznania Bożego objawienia ${ }^{\text {II }}$. Chłodny i krytyczny rozum, oparty na doświadczeniach nauki, zawsze prowadzi do Jezusa. Jedynie powierzchowna nauka od Niego odwodzi. Ateizmu natomiast trzymają się ludzie niepostępowi ${ }^{12}$.

Metropolita nie antagonizował duchowieństwa i inteligencji. Uważał, że nie ma pomiędzy nimi żadnej sprzeczności. Według niego jedynie niewielka część inteligencji była wrogo nastawiona do Cerkwi. Wzywał, aby sprzeciwić się tej garstce, która chciała narzucić wszystkim swoje destrukcyjne idee ${ }^{13}$.

Walczącym z Cerkwią Szeptycki radził, aby najpierw uporali się ze swoimi problemami egzystencjalnymi. Dopiero potem mogą doradzać innym. Prosił, by nie odbierali narodowi wiary i chrześcijańskiej moralności, które dla ubogich ludzi są największym dobrem, nie dając nic w zamian.

Władyka przypominał im, że przez sakrament chrztu świętego należą do chrześcijańskiej wiary i kultury. Tłumaczył, że jeżeli poznają Cerkiew i jej nauczanie, zrozumieją, że ich niechęć do nauki Chrystusa oparta jest na niemających żadnego uzasadnienia uprzedzeniach. Wskazywał ponadto, że rozum człowieka nie jest najwyższym autorytetem ${ }^{\mathrm{I}}$. Stanowczo protestował przeciw fałszywym tezom, jakoby wiara zagrażała postępowi, a Cerkiew nie sprzyjała rozwojowi społeczeństwa. Podkreślał jednocześnie, że nauka Jezusa Chrystusa przyczynia się do wewnętrznego wyzwolenia narodów i sprzyja rozwojowi człowieka na wszystkich płaszczyznach jego życia.

Metropolita Szeptycki przypominał inteligencji, że jej obowiązkiem jest kształtowanie społeczeństwa i wpływanie na jego rozwój swoją powagą, nauką i uczestniczeniem w życiu społeczno-politycznym. Zdawał sobie sprawę, że bez prawdziwej oświaty naród nie osiągnie rozwoju ekonomicznego ani duchowego. Prosił więc inteligencję, aby nie zaniedbywała krzewienia oświaty wśród ludu ${ }^{15}$.

Do nauczycieli apelował, by dbali nie tylko o oświecenie rozumu młodzieży, ale także o uszlachetnienie ich serc. Nie ten naród jest szczęśliwy i bogaty, który ma wielu

\footnotetext{
10 Перше слово..., s. 16.

11 До украӥнської інтелігенції, 29 II 1901 р., w: Твори Слуги..., s. 199-200.

12 Перше слово..., s. 16.

13 Спільне пастирське послання митрополита Шептицького та ін. єпископів до духовенства про солідарність у громадському житті, 11 I 1906, w: Митрополит Андрей Шептицький, Життя і Діяльність. Документи і матеріали 1899-1944, t. 2: Церква і суспільне питання, к. 1: Пастирське вчення та діяльність, ред. А. Кравчук, Львів 1998, s. 351.

14 Перше слово..., s. 15-16.

15 Б. Дзюрак, Виликий і небуденний пастир, w: Митрополит Андрей Шептицький. Документи і матеріали 1899-1944, t. I: Пастирські Послання 1899-1914, ред. М. Гринчишин, Львів 2007, s. XXXI.
} 
teoretyków - tłumaczył władyka - lecz ten, który we wszystkich dziedzinach jest samowystarczalny. Należy więc dzieciom i młodzieży przekazywać wiedzę, dzięki której będą wiedzieli, jak żyć i służyć ojczyźnie ${ }^{16}$.

\section{Kontakty metropolity Andrzeja Szeptyckiego z ukraińską inteligencją}

Metropolita Szeptycki nie bał się i nie unikał dialogu ze współczesną mu kulturą i jej przedstawicielami nawet wtedy, gdy byli krytycznie czy nawet wrogo nastawieni do Cerkwi i jego samego. Nie szukał konfliktów, ale też nie bał się konfrontacji własnych poglądów z przekonaniami przedstawicieli kultury i światowych elit. Jego otwartość, gotowość wysłuchania argumentów strony przeciwnej, ale i konsekwentna obrona prawd świętej wiary, przysparzały mu w kołach inteligencji wiele szacunku ${ }^{17}$.

Pośrednikiem w zbliżeniu pomiędzy metropolitą a ukraińską inteligencją był dr Jewhen Ołesnyćki, działacz społeczno-polityczny, adwokat, ekonomista i publicysta. Był jednym z założycieli Ukraińskiej Partii Narodowo-Ukraińskiej (UNDP) ${ }^{18}$. Należał do grona zaufanych ludzi Szeptyckiego. Władyka uważał go za najlepszego przedstawiciela Ukraińców w parlamencie wiedeńskim ${ }^{19}$. Również Ołesnyćki darzył zaufaniem Szeptyckiego. Wraz z biskupem Konstiantynem Czechowyczem zaproponował jego kandydaturę na metropolitę ${ }^{20}$.

Ołesnyćki prosił Szeptyckiego, aby kapłani sąsiednich parafii mogli na ich terytorium inicjować działalność gospodarczą ${ }^{21}$. Chodziło o prace inicjowane przez towarzystwo „Wiejski gospodarz”, którego rozwój utrudniało zarządzenie Szeptyckiego zabraniające kapłanom prowadzenia działalności w parafiach innych duchownych. Władyka wydał je w związku z tym, że pod koniec XIX w. wielu księży greckokatolickich zaangażowało się w działalność polityczną. Niektórzy nawet ingerowali w życie sąsiednich parafii i atakowali duchownych niepodzielających ich punktu widzenia w sprawach polityki. Wiązało się to z zaniedbaniem obowiązków duszpasterskich ${ }^{22}$. Wbrew zamiarom władyki, utrudniło to działalność towarzystwa „Wiejski gospodarz”, które zajmowało się jedynie działalnością gospodarczą.

Najsłynniejszym przedstawicielem ukraińskiej inteligencji, z którym Szeptycki nawiązał kontakt, był poeta Iwan Franko, najwybitniejszy twórca ukraińskiego języka literackiego w galicyjskiej odmianie, jeden z fundatorów nowoczesnej tożsamości ukraińskiej²3. Oceniał on krytycznie poprzedników metropolity Andrzeja Szeptyckiego. Uważał, że ich listy

\footnotetext{
16 Перше слово..., s. 13.

17 Б. Дзюрак, dz.cyt., s. XIII, XXXI-XXXII.

18 В. Дорошенко, Великий митрополит (Пам'яті митрополита А. Шептицкого. Спогада і нариси), Yorktown 1958, s. 23-24.

19 Лист митр. Андрея Шептицкого до Євгена Олесницкого про украӥнську репрезентацію у Відні та політичну ситуацію в Галичині, 30 VIII 1918, w: Митрополит..., t. 2, к. 2, s. 654-655.

20 В. Дорошенко, dz.cyt., s. 55-56.

21 Лист членів управи Краєвого господарського товариства „Сільський господар” Євгена Олесницкого та Григорія Величка до митр. Андрея Шептиикого про важливість участі духовенства в товариствах „, Сільський господар,", 21 I 1913, w: Митрополит..., t. 2, к. 2, s. 600-601.

22 A. Krawczuk, Metropolita Szeptycki wobec politycznego zaangażowania kleru greckokatolickiego w Galicji, 1900-1914, w: Metropolita Andrzej Szeptycki. Studia i materiaty, red. A. Zięba, Kraków 1994, s. 123-126.

23 M. Jurkowski, Wstęp, w: Stownik ukraińsko-polski i polsko-ukraiński, cz.1: Stownik ukraińsko-polski, red. E. Hrycak, K. Kisielewski, Warszawa 1990, s. XIX-XX.
} 
charakteryzowały się takim lenistwem myśli i szablonowością argumentacji, że trzeba było ofiary i nadzwyczajnej cierpliwości, aby je czytać. Tematyka tych listów często dotyczyła kwestii drugorzędnych. Ich autorzy wykazywali braki w rozumieniu istoty narodowego życia. Szeptycki natomiast - uważał Franko - o tych samych problemach mówił jak Europejczyk. Każdego kto chciał z nim rozmawiać, zmuszał do myślenia ${ }^{24}$. Franko chwalił Szeptyckiego za jego szacunek do ojczystej mowy prostego ludu. Władyka często bowiem przedstawiał swoje myśli galicyjską odmianą języka ukraińskiego, a w głośnym posłaniu do Hucułów nie wstydził się przemawiać dialektem - rzecz dotychczas niesłuchana u cerkiewnych dostojników. Poprzednicy Szeptyckiego - według Iwana Franko - byli ludźmi ograniczonymi, uważającymi się nie tylko za władyków dusz, ale także za władyków mowy. Poeta cenił Szeptyckiego także za to, że traktował adresatów swoich listów i przemówień jako równych sobie ludzi. Nigdy nie używał autorytarnego tonu. Gdy jednak było to konieczne, nie bał się użyć ostrych słów. Czasami po prostu łajał swoich wiernych za nieprzestrzeganie nauki Cerkwi. Franko podkreślał nadto zdolność metropolity do trafnej oceny rzeczywistości i posiadanie życiowej mądrości. Według niego Szeptycki o wiele lepiej niż jego poprzednicy znał życie i jego rzeczywiste problemy. Filozof cenił go także za jego szacunek do ludzi, w szczególności do prostego ludu i dbałość o jego duchowe i intelektualne wykształcenie ${ }^{25}$.

Mimo wielkiego szacunku do metropolity Iwan Franko nie szczędził mu jednak krytycznych uwag. Dotyczyły one głównie tez zawartych przez Szeptyckiego w jego liście pasterskim omawiającym kwestie socjalne. Metropolita przestrzegał przed postępującym „duchem nieposłuszeństwa” dla władzy, który przejawiał się w dążeniu do przesadnej wolności i absolutnej równości wszystkich ludzi. Teoria liberalna głosiła także równe prawa społeczne dla wszystkich. Brakowało jednak refleksji nad pytaniem, czy możliwe jest zrealizowane tych postulatów. Według Szeptyckiego tak rozumiany postęp prowadzi do eskalacji nastrojów rewolucyjnych i w konsekwencji może sprowadzić na naród ukraiński olbrzymie nieszczęście ${ }^{26}$.

W odpowiedzi na te poglądy metropolity Iwan Franko zarzucił mu brak znajomości historii. Według niego nigdy dotychczas panujący nie czuli się tak bezpiecznie wśród poddanych jak w czasach im współczesnych. Ludzie bowiem - twierdził poeta - z mniejszym przymusem, a często dobrowolnie, wykonywali rozporządzenia władzy. Za wszelkie natomiast zaburzenia społeczne i rewolucje winę według niego ponosiła władza państwowa, która wywoływała je swymi systematycznymi nadużyciami i brakiem szacunku dla zasad sprawiedliwości społecznej. Dlatego Franko pytał ironicznie Szeptyckiego, do jakiego to nieszczęścia może doprowadzić naród ukraiński pielęgnowanie ducha bezwzględnej walki przeciw wszelkiej niesprawiedliwości ${ }^{27}$. Filozof nie dostrzegał zagrożenia wynikającego z rozwijającego się ruchu komunistycznego, który doprowadził do wybuchu krwawej rewolucji październikowej w Rosji. Boleśnie odczuła to także Cerkiew greckokatolicka, która w 1946 r. została zlikwidowana przez bolszewików ${ }^{28}$.

\footnotetext{
24 Стаття Івана Франка „Сочіальна акція, соичіальне питання і соиіалізм. Уваги над Пастирським посланієм митрополита А. Шептицкого „О квестї соціальній, 1904, w: Митрополит..., t. I, s. 837.

25 Tamże, s. 837-839.

26 Пастирське послання митрополита Шептицкого до духовенства „О квестї̈ соичіальній”, $21 \mathrm{~V} 1904$ r., w: Митрополит ..., t. 2, к. 1, s. 146-147.

27 Стаття..., s. 845.

28 С. Баран, Митрополит Андрей Шептицький, Життя і Діяльність, München 1947, s. 137-142.
} 
Franko nie zgadzał się też z opinią Szeptyckiego na temat liberalizmu ${ }^{29}$. Metropolita poddał ostrej krytyce teorię pracy, którą głosiła szkoła liberalnych ekonomistów. Uznał ją za fałszywą, gdyż według niej sprawiedliwą mogła być płaca niska, która skazywała robotnika i jego rodzinę na życie w skrajnej nędzy. Teoria ta uważa pracę za towar, którego wartość oznacza proporcja popytu i podaży. Według niej sprawiedliwa jest każda płaca, którą robotnik może osiągnąć, a którą pracodawca jest zmuszony dać bez względu na to, jaka jest proporcja pomiędzy pracą a zapłatą ${ }^{30}$. Aby rozwiązać kwestię sprawiedliwości-podkreślał metropolita - ustrój polityczny musi być oparty na Chrystusowym przykazaniu miłości. To przykazanie jest potrzebne do sprawiedliwego traktowania bliźnich ${ }^{31}$. Według Iwana Franka chrześcijańska teoria pracy nie różniła się od teorii liberalnej, ponieważ każda z nich uczy, że pracodawca zobowiązuje się wypłacić za pracę sprawiedliwe, umówione wynagrodzenie. Ponadto - wskazywał filozof - liberalizm nie wyklucza sprawiedliwości. Przy pogłębionej analizie poglądów Franka można zauważyć, że poeta nie dostrzegał różnicy pomiędzy sprawiedliwością opartą wyłącznie na ludzkich przekonaniach, sprowadzających się często do „prawa silniejszego”, a sprawiedliwością wynikającą z przykazania miłości bliźniego ${ }^{32}$.

Iwan Franko nie zgadzał się także z poglądami Szeptyckiego na temat socjalizmu. Według niego socjalizm jako coś jednolitego nie istnieje. Uważał, że istnieją różne teorie socjalizmu. Główne zarzuty metropolity wobec socjalizmu uważał za nieprawdziwe. Twierdził, że uznanie religii i moralności za prywatną sprawę człowieka, podważanie prawa prywatnej własności, dążenie do absolutnej równości pomiędzy ludźmi i negowanie rodziny, nie jest wymysłem socjalistów. Argumentem potwierdzającym według poety tę tezę był fakt, że nie tylko socjaliści mają takie przekonania. Twierdził, że prawo posiadania ziemi jest rzeczą nową, a np. pomysły upaństwowienia poczty, kolei, itd. nie wyszły od socjalistów. Jednak wywody Franka oparte są na typowo socjalistycznych przesłankach. Wyróżniał on dwa rodzaje własności: produkcyjną, która ma charakter społeczny, i konsumpcyjną, która ma charakter indywidualny. Jak łatwo dostrzec poeta podważa tradycyjne pojęcie prawa własności jako prawa do posiadania rzeczy i zastępuje je prawem do używania. Przyjmując taki sposób myślenia, wszystko można uznać za społeczne, a własność prywatna przestaje istnieć33.

Pomimo swego krytycznego nastawienia do socjalizmu, metropolita nie dostrzegał zagrożenia, jakie wynikało z propagowania wśród wiernych socjalistycznych i ateistycznych idei Franka. W latach dwudziestych XX w. wśród grekokatolików w USA zaczął rozwijać się kult Iwana Franka. Główną siłą inspirującą było towarzystwo „Zjednoczenie”, które pod pozorami troski o dobro Cerkwi dążyło do jej rozbicia.

Konstanty Bogaczewski, biskup dla grekokatolików w USA, wystąpił przeciw szerzącemu się kultowi ateizmu. Obawiał się, że jego efektem będzie propaganda antycerkiewnych idei Franka. Naraził się w ten sposób na krytykę części ukraińskiej inteligencji. Zwrócił się więc o pomoc do Szeptyckiego. Koronnym bowiem argumentem zwolenników kultu w ich destrukcyjnej agitacji był brak sprzeciwu ze strony metropolity. Uważali, że lwowski władyka

\footnotetext{
29 Стаття..., s. 845.

30 Пастирське..., 21 V 1904 r., s. 155.

31 Tamże, s. 140, 158-161.

32 Стаття..., s. 852-853.

33 Tamże, s. 853-855.
} 
należy do grona wielbicieli geniuszu Franka ${ }^{34}$. Metropolita Szeptycki nie podzielał jednak obaw bpa Konstantyna Bogaczewskiego. Oznajmił, że gdyby ateizm, materializm i racjonalizm stanowiły istotę twórczości Franka, zabroniłby duchowieństwu i wiernym propagować jego idee. Uważał jednak, że sprawy te zajmowały w jego myśli niewielki margines. Istotę natomiast stanowiły sprawy narodowe i patriotyczne. Dlatego zostanie zapamiętany jako poeta-narodowiec. Według Szeptyckiego wierni poddani jego jurysdykcji szanują Franka wyłącznie jako pisarza-patriotę, odrzucają jednak jego światopogląd ${ }^{35}$.

Metropolita z pewnością nie chciał wystąpić przeciwko Iwanowi Franko także dlatego, że darzył go dużym szacunkiem. W I9I3 r. uczestniczył w uroczystym jubileuszu poety. Na dobre relacje pomiędzy Szeptyckim i Franko wskazuje również wizyta, jaką władyka złożył w jego domu.

Przyjacielskie relacje łączyły Szeptyckiego także z Wołodymyrem Antonowyczem, pionierem ukraińskiego ruchu narodowego w Rosji, profesorem historii Uniwersytetu Kijowskiego, archeologiem i etnografem. Z pochodzenia był Polakiem, wrócił jednak do narodowości porzuconej niegdyś przez przodków ${ }^{36}$. Poznali się Kijowie w I887 r. Anonowycz wywarł na późniejszym metropolicie duże wrażenie ${ }^{37}$. Wołodymyr Antonowycz należał do istniejącego w latach I857-I86I r. w środowisku studentów Uniwersytetu Kijowskiego „Związku Trojańskiego”. Część jego członków, z Antonowyczem na czele, była związana z ukraińskim ruchem narodowym, który włączył się do pracy oświatowo-kulturalnej. Ich ważnym dziełem były powstałe w miastach szkółki niedzielne dla dzieci rzemieślników ${ }^{38}$.

Na polu budzenia ukraińskiej świadomości narodowej Szeptycki współpracował także z Mychajłem Hałuszczyńskim, ukraińskim politykiem i działaczem oświatowym, wicemarszałkiem Senatu II RP39. Był jednym z założycieli Ukraińskiego Zjednoczenia Narodowo-Demokratycznego (UNDO), a także prezesem Towarzystwa Proświta”. Hałuszczyński prosił władykę, by użył swych wpływów, aby w społeczeństwie polskim wzmacniało się stronnictwo konserwatywne, przychylne Rusinom. Obawiał się, że polskie życie polityczne zostanie zdominowane przez zwolenników idei wszechpolskiej, czyli solidaryzmu narodowego. Uważał, że spowoduje to rozwój polskiego nacjonalizmu, który, prowadząc naród polski do katastrofy, pociągnie za sobą także Rusinów ${ }^{40}$.

Do grona bliskich znajomych metropolity Szeptyckiego należał także hrabia Mychajło Tyszkewycz, dyplomata i publicysta. Należał do spolszczonego ukraińsko-litewskiego arystokratycznego rodu. Dorastał poza Ukrainą - w Warszawie i Wilnie. Po ukończeniu nauki, zachwycony historią i przyrodą Ukrainy, powrócił do domu, do swoich korzeni. Wstąpił do

\footnotetext{
34 Лист єпископа Констянтина Богачевського до митр. Андрея Шептицького про вплив творчості Івана Франка на народ, 16 XI 1926, w: Митрополит..., t. 2, к. 2, s. 785-787.

35 Лист митр. Андрея Шептииького до украӥнського епископа в Філадельфії Констянтина Богачевського про вплив творчості Івана Франка на суспільність, 21 ХІІ 1926, w: Митрополит ..., t. 2, к. 2, s. $791-794$.

36 К. Левицкий, Історія політичної думки галицких українців 1848-1914, ч. 2, Львів 1927, s. 386.

37 R. Torzecki, Kwestia ukraińska w Polsce w latach 1923-1929, Kraków 1989, s. 386.

38 K. Grünberg, B. Sprengel, Trudne sąsiedztwo. Stosunki polsko-ukraińskie w X-XX wieku, Warszawa 2005, S. 130 .

39 Tamże, s. 390, 413, 415.

40 Лист громадсько-політичного діяча М. Галущчинського до митр. Андрея Шептицького про діяльність Народної Ради, 27 XII 1902 р., w: Митрополит..., т. 2, к. 2, s. 577-579.
} 
Petersburskiej Akademii Sztuk Pięknych, gdzie stał się świadomym Ukraińcem ${ }^{41}$. W lutym I9I9 r. rząd Ukraińskiej Republiki Ludowej (URL) wyznaczył go na stanowisko przewodniczącego przedstawicielstwa dyplomatycznego w Watykanie. Po wypełnieniu tego zadania został przewodniczącym ukraińskiej misji przy kongresie pokojowym w Paryżu ${ }^{42}$. W czasie pobytu w Rzymie prosił papieża, aby poparł dążenia Ukraińców do stworzenia własnego państwa. Według jego relacji Ojciec Święty popierał dążenia Ukraińców ${ }^{43}$.

Szeptycki doceniał patriotyzm i poświęcenie się Tyszkewycza dla dobra narodu ukraińskiego. Dyplomata mógł liczyć na pomoc władyki44. Tyszkewycz bronił politycznych interesów Galicji Wschodniej. Swoich wpływów użył szczególnie w I9I8 r., gdy groziło niebezpieczeństwo przyłączenia jej do Rosji. Uważał, że jedynie monarcha niemiecki albo austriacki może dać Ukraińcom pełną gwarancję, że do tego nie dojdzie ${ }^{45}$. Było to zgodne z przekonaniami Szeptyckiego, który także uważał, że Galicja Wschodnia powinna trwać w jedności z Austrią. Według niego zabezpieczało to ją przed przyłączeniem do Polski ${ }^{46}$. Według Tyszkewycza Galicja powinna w przyszłości stać się ukraińskim Piemontem. Przestrzegał przed działaniami prawosławnego biskupa Eulogiusza (Wasilij Gieorgijewski) i Pawła Skoropadskiego, którzy chcieli przyłączyć Galicję Wschodnią do Rosji ${ }^{47}$.

Dobre kontakty utrzymywał Szeptycki także z Kostiem Łewyćkym, adwokatem i publicystą, posłem do parlamentu austriackiego i sejmu galicyjskiego, przewodniczącym Ukraińskiego Klubu Parlamentarnego w Wiedniu. W listopadzie I9I8 r. Łewyćki został premierem Zachodnio-Ukraińskiej Republiki Ludowej (ZURL) ${ }^{48}$. Często zwracał się do metropolity o radę w kwestiach politycznych, społecznych i narodowych. Szeptycki poparł jego kandydaturę na stanowisko premiera ZURL. Nie obawiał się jednak krytykować go, gdy podejmował niewłaściwe decyzje ${ }^{49}$. O ścisłej współpracy Szeptyckiego z Łewyćkim świadczy prośba skierowana przez Łewyćkiego do metropolity o materialną pomoc dla galicyjskiej emigracji politycznej. Aby wspierać przebywających na emigracji działaczy politycznych,

\footnotetext{
41 Б. Андрусишин, Церква в українській державі 1917-1920 рр. (доба директорії), Київ 1977, s. 62-64.

42 Коментарі, w: Митрополит..., t. 2, к. 2, s. 1036.

43 Фрагмент звітудипломата УНР графа Михайла Тишкевичазі своєїпраиі та про визнання Апостольською Столицею права украӥнського народу на самостійну державу, 1919-1920 (Рагуд்), w: Митрополит..., t. 2, к. 2, s. 699.

44 Лист митр. Андрея Шептиикого до дипломата УНР графа Михайла Тишкевича, 1 XII 1917 , w: Митрополит..., t. 2, к. 2, s. 660-661.

45 Лист дипломата УНР графа Михайла Тишкевича до митр. Андрея Шептиикого про умови отримання Украӥною самостійності, 7 VI 1918, w: Митрополит..., t. 2, к. 2, s. 683.

46 Лист митр. Андрея Шептицкого до дипломата й посла УНР графа Михайла Тишкевича про майбутне Української держави, 25 I 1918, w: Митрополит..., t. 2, к. 2, s. 669-670.

47 Лист дипломата УНР графа Михайла Тишкевича до митр. Андрея Шептицкого з оцінку політичною становищя в Украӥні та прохання призначити делегатів від Украӥни, 01 XI 1918, w: Митрополит..., t. 2, к. 2, s. 689-690.

48 Коментарі, s. 1036.

49 A. Kubasik, Arcybiskupa Andrzeja Szeptyckiego wizja ukraińskiego narodu, państwa i Cerkwi, Lwów-Kraków 1999 , s. $65,74,87-88$.
} 
utworzono specjalny komitet5 ${ }^{50}$. Szeptycki w miarę swoich możliwości wspierał działających na rzecz dobra narodu ukraińskiego. Dlatego bez wahania spełnił prośbę działacza ${ }^{5}$.

Warto podkreślić, że Szeptycki cenił wszystkich, którzy działali na rzecz narodowej sprawy. Świadczy o tym jego list do Dmytra Łewyćkiego, redaktora gazety „Diło”. Czasopismo to zajmowało w sprawach wiary i religii stanowisko, z którym Szeptycki nie mógł się zgodzić. Przyznał jednak, że „Diło” zawsze uczciwie i sumiennie broniło sprawy narodowej. Położyło wielkie zasługi dla rozwoju narodu ukraińskiego ${ }^{52}$.

Na uwagę zasługuje także współpraca Szeptyckiego z Wołodymyrem Kubijowyczem, geografem i etnografem. Metropolita podkreślał znaczenie pracy nauczycieli rysunku w formowaniu świadomości narodowej ukraińskiej młodzieży. Uważał, że ukraińska młodzież uczęszczająca do polskich szkół, nie znała najważniejszych historycznych postaci swego narodu. Nauczyciele rysunku powinni więc podjąć pracę na tym polu, aby w ten sposób wzmocnić w młodzieży przywiązanie do ukraińskiego narodu i jego tradycji. Ukraiński hierarcha prosił Kubijowycza, aby zaangażował się w projekt ukraińskich artystów, którzy chcieli utworzyć szkołę dla nauczycieli rysunku³. Kubijowycz wyraził gotować podjęcia się realizacji tych zamierzeń. Nie wierzył jednak, aby w czasie wojny można było te plany urzeczywistnić54.

Inteligencja ukraińska oczekiwała po metropolicie Szeptyckim że będzie on bronić praw swego narodu. Był to czas, gdy ważyły się losy Galicji Wschodniej. Ukraińcy galicyjscy nie chcieli dopuścić, aby została przyłączona do Polski. Uważali, że obowiązkiem metropolity było wsparcie tej sprawy ${ }^{55}$. Do niego zwracano się w chwilach trudnych. Proszono go o interwencję, gdy władze polskie uchwalały niekorzystne dla Ukraińców prawa ${ }^{56}$.

Dla dużej części ukraińskiej inteligencji Szeptycki był autorytetem tylko wtedy, gdy zabierał głos jako przywódca polityczny narodu ukraińskiego. Jego nauczanie dotyczące spraw wiary i moralności nie miało dla nich zbyt wielkiego znaczenia ${ }^{57}$. Szczególnie dostrzegalne było to w czasie okupacji bolszewickiej Małopolski Wschodniej w latach I939-I94I. Nie było

\footnotetext{
50 Лист д-ра Костя Левиикого до митр. Андрея Шептиикого про заснування Організаційного Комітету західноукраїнської політичної еміграції та прогання матеріальної допомоги, 26 II 1924, w: Митрополит ..., t. 2, к. 2, s. 766-767.

51 Лист голови Комітету західноукраїнської еміграції д-ра Костя Левицкого з подякою за подтримку політичної еміграції, 22 IV 1924, w: Митрополит..., t. 2, к. 2, s. 768.

52 Лист митр. Андрея Шептицького до редактора газети ,Діло ”Дмитра Левицького з визнанням заслуг газети перед народом, 1930, w: Митрополит..., t. 2, к. 2, s. 817.

53 Лист митр. Андрея Шептицького до проф. Володимира Кубійовича про завдання украӥнської мистецькой школи у патріотичному вихованні молоді, 8 VIII 1942 r., w: Митрополит..., t. 2, к. 2, s. 978-979.

54 Лист проф. Володимира Кубійовича до митр. Андрея Шептицького про мистецької школу для вчителів рисунків, 22 VIII 1942 r., w: Митрополит..., t. 2, к. 2, s. 979-980.

55 Лист проф. Івана Полюя до ТеоФіля Окуневського, посла до ради державної у Відні, 20 XI 1917 , w: Митрополит ..., t. 2, к. 2, s. 658-660.

56 Лист голови УНДО та Української Парламентарної Репрезентації (Дмитра Левиикого) до митр. Андрея Шептицького з проханням підтримати протестаційну акцію проти політики польських законодавчих установ стосовно украӥнського народу, 6 XII 1932, w: Митрополит..., t. 2, к. 2, s. 979-980.

57 Звіт митр. Андрея Шептицького для о. Д. Дженнокі про стан Львівської Архієпархї, 12 II 1923, w: Митрополит..., t. 2, к. 2, s. 717.
} 
co prawda formalnych i skandalicznych odstępstw od wiary, ale profesorowie, dyrektorzy szkół, pisarze i artyści, unikali kapłanów ${ }^{58}$.

Należy jednak podkreślić, że również w tej grupie społecznej znajdowali się wierni Cerkwi greckokatolickiej, którzy szukali w nauce metropolity odpowiedzi na pytania dotyczące codziennego życia. Jako przykład można podać list skierowany do niego przez pisarza Andrija Czajkowskiego, przewodniczącego towarzystwa pisarzy i dziennikarzy we Lwowie ${ }^{59}$. Listy pasterskie Szeptyckiego były dla niego głosem arcypasterza do swej owczarni. Uważał, że były potrzebne ludziom, którzy chcą żyć po chrześcijańsku. W jego nauczaniu znalazł odpowiedź na szereg nurtujących go pytań. Dzięki władyce zrozumiał, że nie trzeba żyć w nędzy, aby wejść do Królestwa Bożego. Nie łamie nauki Chrystusa człowiek, który w godziwy sposób zdobywa dobra materialne. Dotychczas był przekonany, że tylko biedni mogą być zbawieni' ${ }^{60}$.

To właśnie Czajkowski zwrócił uwagę Szeptyckiego na brak Pisma Świętego w ich narodowej mowie. Biblię uważał za najważniejszą książkę, zarówno dla inteligenta jak i prostego człowieka. Była dla niego źródłem Bożej prawdy i nauki. Według niego każdy naród rozpoczyna swoją kulturę od przekładu Pisma Świętego ${ }^{61}$.

Omawiając relacje Szeptyckiego z ukraińską inteligencją, należy wspomnieć jego działalność na rzecz zjednoczenia Cerkwi. W tym celu skierował list do prawosławnej, wierzącej inteligencji ${ }^{2}$. Jednak propozycja Szeptyckiego została przyjęta negatywnie. Prawosławni odpowiedzieli, że ich prawosławna Cerkiew nigdy nie odeszła od powszechnej prawosławnej wschodniej Cerkwi i dlatego nie musi z nikim się jednoczyć. Pojednanie, które proponował Szeptycki, odebrano jako próbę przyłączenia prawosławia do Rzymu. Ponieważ dogmat o prymacie papieża był dla nich uzurpacją, propozycja Szeptyckiego była dla nich nie do przyjęcia $^{63}$.

\section{Stosunek Szeptyckiego do inteligencji polskiej obrządku greckokatolickiego}

Relacje pomiędzy metropolitą Szeptyckim a polską inteligencją należącą do Cerkwi greckokatolickiej, były bardzo skomplikowane. Mimo zapewnień, że Polacy należący do Cerkwi greckokatolickiej są mu bardzo drodzy ${ }^{64}$, prowadził politykę antypolską. W jej efekcie tysiące Polaków-grekokatolików porzuciło Cerkiew greckokatolicką i przeszło na obrządek łaciński. Wśród nich były powszechnie znane polskie rodziny inteligenckie ${ }^{65}$.

\footnotetext{
58 Лист митр. Андрея Шептииького до нуниія Ротти у Будапешті про стан Лвівської Архієпархї̈, 07 XI 1941 r., w: Митрополит..., t. 2, к. 2, s. 953-954.

59 Коментарі, s. 1031.

60 Лист письменника Чайковського Андрія до митр. Андрея Шептицького про оцінку інтелігенцією Пастирських послань митрополита до народу та про потребу перекладу Святого Письма, $30 \mathrm{~V} 1901$, w: Митрополит..., t. 2, к. 2, s. 571-572.

61 Tamże, s. 572-573.

62 Мій лист до української віруючої православної інтелігенції, 3 III 1942, w: Письма..., wуd. М. Гринчишин, Yorkton, Sask 1969, s. 340-342.

63 Одвертий лист украӥнської православної інтелігенциї до митрополита Андрея Шептицького, kwіесіеп́ 1942 r., w: Письма..., s. 345-346.

64 List pasterski metropolity Andrzeja Szeptyckiego do Polaków obrządku greckokatolickiego, 16 V 1904, w: Metropolita Andrzej Szeptycki. Pisma wybrane, red. M. Szeptycki, M. Skórka, Kraków 2000, s. 92-107.

65 J. Giertych, L'eglise en Pologne Orientale. Lettre ouverte au Redacteur des «Informations catholiques internationales» a Paris, Londres 1963, s. 12-13.
} 
Aby przeciwdziałać prześladowaniu Polaków-grekokatolików, grupa polskiej inteligencji greckokatolickiej z prof. Teofilem Stupnickim na czele zaczęła wydawać w Krakowie pismo „Greko-katolik”. W I937 r. wystosowała list do biskupów greckokatolickich, w którym domagała się zapewnienia im praw w Cerkwi greckokatolickiej. W liście tym Polacy-grekokatolicy podkreślali, że Cerkiew unicka zażywa w Polsce pełni swobód, a nawet cieszy się specjalnymi przywilejami Stolicy Świętej i polskiego rządu. Natomiast Polacy grekokatolicy są we własnej Cerkwi prześladowani. Autorzy listu zwrócili się do biskupów, a w szczególności do metropolity Szeptyckiego, o wydanie duchowieństwu polecenia, by respektowało prawa wiernych polskiej narodowości. Polacy dopominali się, by w ich cerkwiach w duszpasterstwie używany był język polski ${ }^{66}$. Ponadto domagali się dopuszczenia do seminarium duchownego, zaprzestania kazań politycznych i poniżania narodu i państwa polskiego. Jednak apel polskiej inteligencji do biskupów pozostał bez odpowiedzi i nie przyniósł oczekiwanej poprawy sytuacji Polaków należących do Cerkwi greckokatolickiej ${ }^{67}$.

\section{Zakończenie}

Dzięki swej służbie na rzecz narodu ukraińskiego metropolita Szeptycki stał się niekwestionowanym autorytetem dla Ukraińców z Małopolski Wschodniej. Przedstawiciele ukraińskiej inteligencji chętnie nawiązywali z nim kontakt, ponieważ jego poparcie ułatwiało realizację różnego rodzaju przedsięwzięć politycznych i społecznych. Jednak jego nauczanie dotyczące spraw wiary i moralności było im obojętne. Brak przesłanek, w oparciu o które można by wykazać, że przepowiadanie przez Szeptyckiego słowa Bożego wpłynęło na pogłębienie ich życia religijnego.

\section{The relationship between the Metropolitan Archbishop Andrey Sheptytsky and the Ukrainian intelligentsia Summary}

The Metropolitan Archbishop Andrey Sheptytsky was the head of the Greek Catholic Church in Eastern Małopolska in I9OI-I946. When he assumed the duties of a bishop, he realised that work with the intelligentsia would be more difficult than with other people. However, he still wished to be their spiritual leader in their Christian life. He never wanted to set the clergy against the intelligentsia; he did not believe they were in opposite camps. He summoned those who declared they affiliation with the Greek Catholic Church to manifest it in their everyday living. Moreover, he opposed those who demanded that the Greek Catholics join the Orthodox Church for the sake of national unity of the Ukrainians.

Many people representing the world of culture and science considered him as the most important defender of the Ukrainian nation's rights.

Keywords: Metropolitan Andrey Sheptytsky, Ivan Franko, Ukrainian intelligentsia, anticlericalism, socialism, Polish-Greek Catholics

${ }^{66}$ T. Jagmin, Polacy grekokatolicy na Ziemi Czerwieńskiej, Lwów 1939, s. 6, 21-24.
${ }_{67}$ Tamże, s. 8. 


\section{BIBLIOGRAFIA}

Teksty źródłowe

Перше лово пастиря. (Пастирський лист до вірних Станиславівської Спархї, I899 р.), w: Твори Слуги Божсого Митрополита Андрея Шептииького - пастирські листи (2 VIII I899 p. - 7 IX I9oI p.), wyd. А. Базилевич, Toronto I965, s. I-I9. (Perše slovo pastirâ (Pastirs'kij list do virnih Stanislavivs'koï Êparhï, I899 r.), w: Tvori Slugi Božogo Mitropolita Andreâ Šeptic'kogo-pastirs'ki listi, wyd. A. Bazilevic, Toronto I965).

Наша програма. Пастирський лист до духовенства станиславівської спархї, I899, w: Tвори Слуги..., s. 20-28. (Naša programa. Pastirs'kij list do duhovenctva Stanislavivs'kö̈ Éparhï̈, I899, w: Tvori Slugi...).

До украӥнської інтелігениії, 9 II I9оI р., w: Твори Слуги..., s. I90-2I4. (Do ukraїns'koї inteligenciï, 9 II I9OI, w: Tvori Slugi...).

Лист письменника Чайковського Андрія до митр. Андрея Шептицького про оиінку інтелігенцією пастирських послань митрополита до народу та про потребу перекладу Святого Письма, зо V I9оI, w: Митрополит Андрей Шептицький, Життя і Діяльність. Документи і матеріали 1899-1944, t. 2: Церква і суспільне питання, к. 2: Листування, ред. А. Кравчук, Львів 1999, s. 57I-574. (List pis'mennika Čajkovc'kogo do mitr. Andreâ Šeptic'kogo pro ocinku inteligenciêû pastirs'kih poslan' mitropolita do narodu ta pro potrebu perekladu Svâtogo Pis'ma, 30 V I9oI, w: Mitropolit Andrej Šeptic'kij, Žittâ i Diâlnìst'. Dokumenti i matepiali, t. 2: Cerkva ì suspil'ne pitannâ, k. 2: Listuvannâ, red. A. Kravčuk, L’vìv I999).

Лист громадсько-політичного діяча М. Галущчинського до митр. Андрея Шептицького про діяльність Народної Ради, 27 ХІІ 1902 р., w: Митрополит..., t. 2, к. 2, s. 577-579. (List gromads'ko-političnogo dîača M. Galuŝins'kogo do mitr. Andreâ Šeptic’kogo pro diâlnist Narodnö̈ Padi, 27 XII I902, w: Mitropolit..., t. 2, к. 2).

List pasterski metropolity Andrzeja Szeptyckiego do Polaków obrzadku greckokatolickiego, I6 V I904, w: Metropolita Andrzej Szeptycki. Pisma wybrane, red. M. Szeptycki, M. Skórka, Kraków 2000, s. 92-I07.

Пастирське послання митрополита Шептицкого до духовенства „О квестіі соиіальній”, 2 V V 1904 r., w: Митрополит Андрей Шептиџький, Життя і Діяльність. Документи і матеріали I899-I944, t. 2: Церква і суспільне питання, к. I: Пастирське вчення та діяльність, ред. А. Кравчук, Львів I998, s. I37-I47. (Pastirs'ke poslannâ mitropolita Šeptic'kogo do duhovenstva ,O kvestï social'nij”, 2 I V I904, w: Mitropolit Andrej Šeptic'kij, Žittâ i Diâlnist'. Dokumenti i matepiali, t. 2: Cerkva i suspil'ne pitannâ, к. I: Pastirs'ke včennâ ta dil'nist', red. Kravčuk, L'vìv I998).

Стаття Івана Франка „Соціальна акиія, соціальне питання і соиіалізм. Уваги над Пастирським посланієм митрополита А. Шептицкого „О квестї̈ соціальній, I904, w: Митрополит Андрей Шептицький. Документи і матеріали I899-I944, t. I: Пастирські Послання I899-I9I4, ред. М. Гринчишин, Львів 2007, s. 837-856. (Stattâ Ìvana Franka ,,Social'na akciâ, Social'ne pitannâ i socializm. Uvagi nad Pastirs'kim poslaniêm mitropolita A. Šeptic'kogo „O kvestï social'nij”, I904, w: Mitropolit Andrej Šeptic'kij, Dokumenti i matepiali, t. I: Pastirs'ki Poslannâ, red. M. Grinčišin, L'vìv 2007).

Спільне пастирське послання митрополита Шептицького та ін. єпископів до духовенства про солідарність у громадськомужитті, ІІ I I9o6, w: Митрополит..., 
t. 2, к. I, s. 349-357. (Spil'ne pastirs'ke poslannâ mitropolita Šeptic'kogo ta ìn. Êpiskopìv do duhovenstva pro solidarnist' y gromads'komu žitti, II I I9o6, w: Mitropolit..., t. 2, к. I). Лист членів управи Краєвого господарського товариства „Сільський господар” Євгена Олесницкого та Григорія Величка до митр. Андрея Шептицєкого про важливість участі духовенства в товариствах „Сільський господар”, 2I I I9I3, w: Митрополит..., t. 2, к. 2, s. 600-602. (List členìv upravi Kraêvogo gospodars'kogo tovaristva ,Sil's'kij gospodar” Êvgena Olesnickogo ta Grigoriâ Velička do mitr. Andreâ Šeptic' kogo pro važlivist' učastì duhovenstva v tovaristvah ,, Sil's'kij gospodar”, 2 I I I9I3, w: Mitropolit..., t. 2, к. 2).

Лист проф. Івана Полюя до ТеоФіля Окуневського, посла до ради державної у Відні, 20 XI I9I7, w: Митрополит..., t. 2, к. I, s. 658-66o.(List prof. Ivana Polûâ do Teofillâ Okunevs'kogo, posla do radi deržavnoï u Vidni, 20 XI I9I7, w: Mitropolit..., t. 2, к. I).

Лист митр. Андрея Шептиикого до дипломата УНР графа Михайла Тишкевича, I ХІІ I9I7, w: Митрополит..., t. 2, к. 2, s. 660-66I. (List mitr. Andreâ Šeptic'kogo do diplomata UNR grafa Mihajla Tiškeviča, I XII I9I7, w: Mitropolit..., t. 2, к. 2).

Лист митр. Андрея Шептицкого до дипломата й посла УНР графа Михайла Тишкевича про майбутне Украӥнської держави, 25 I I9I8, w: Митрополит..., t. 2, к. 2, s. 669-670. (List mitr. Andreâ Šeptic'kogo do diplomata j posla UNR grafa Mihajla Tiškeviča pro majbutne Ukraïns'koï deržavi, 2 I I I9I8, w: Mitropolit..., t. 2, к. 2).

Лист дипломата УНР графа Михайла Тишкевича до митр. Андрея Шептицкого про умови отримання Украӥною самостійності, 7 VI I9I8, w: Митрополит..., t. 2, к. 2, s. 683. (List diplomata UNR grafa Mihajla Tiškeviča do mitr. Andreâ Šeptic'kogo pro umovi otrimannâ Ukraïnô̂ samostìjnostì, 7 VI I9I8, w: Mitropolit..., t. 2, к. 2).

Лист митр. Андрея Шептииякого до Євгена Олесницкого про українську репрезентацію у Відні та політичну ситуаџію в Галичині, зо VIII I9I8, w: Митрополит..., t. 2, к. 2, s. 654-655. (List mitr. Andreâ Šeptic'kogo do Êvgena Olesnickogo pro ukrä̈ns'ku reprezentaciû u Vidnì ta političnu situacîu v Galičini, 30 VIII I9I8, w: Mitropolit..., t. 2, к. 2).

Фрагмент звіту дипломата УНР графа Михайла Тишкевича зі своєї праиі та про визнання Апостольською Столицею права украӥнського народу на самостійну державу, I9I9-I920 (Paryż), w: Митрополит..., t. 2, к. 2, s. 698-699. (Fragment zvitu diplomata UNR grafa Mihajla Tiškeviča zi svoêi pracì ta pro viznannâ Apostol's'kô̂ Stolicê̂ prava ukraïns'kogo narodu na samostìjnu deržavu, I9I9-I920, w: Mitropolit..., t. 2, к. 2).

Лист д-ра Костя Левицкого до митр. Андрея Шептицєкого про заснування Організаційного Комітету західноукраӥнської політичної еміграції та прогання матеріальної допомоги, 26 II I924, w: Митрополит..., t. 2, к. 2, s. 766-767. (List d-ra Kostâ Levickogo do mitr. Andreâ Šeptic'kogo pro zasnuwannâ Organizacìjnogo Komitetu zahidnoukraïns'koï političnoï emigracï ta progannâ material'nö̈ dopomogi, 26 II I924, w: Mitropolit..., t. 2, к. 2).

Лист голови Комітету західноукраӥнської еміграції д-ра Костя Левицүкого з подякою за подтримку політичної еміграції, 22 IV I924, w: Митрополит..., t. 2, к. 2, s. 768. (List golovi Komitetu zahidnoukrä̈ns'kö̈ emigracï d-ra Kostâ Levickogo z podâkô̂ za podtrimku političnoï emigracï, 22 IV I924, w: Mitropolit..., t. 2, к. 2). 
Лист єпископа Констянтина Богачевського до митр. Андрея Шептицького про вплив творчості Івана Франка на народ, І6 XI 1926, w: Митрополит..., t. 2, к. 2, s. 785787. (List êpiskopa Konstântina Bogačews'kogo do mitr. Andreâ Šeptic'kogo pro vpliv tvopčostì Ivana Franka na narod, I6 XI I926, w: Mitropolit..., t. 2, к. 2).

Лист митр. Андрея Шептицького до українського епископа в Філадельфї Констянтина Богачевського про вплив творчості Івана Франка на суспільність, 2I XII I926, w: Митрополит..., t. 2, к. 2, s. 79I-794. (List mitr. Andreâ Šeptic'kogo do ukrä̈ns'kogo êpiskopa v Filadel'fï Konstântina Bogačews'kogo pro vpliv tvopčostì Ivana Franka na suspil'nist', 2 I XII I926, w: Mitropolit..., t. 2, к. 2).

Лист митр. Андрея Шептищького до редактора газети „Діло”Дмитра Левицького з визнанням заслуг газети перед народом, І93о, w: Митрополит..., t. 2, к. 2, s. 8I7. (List mitr. Andreâ Šeptic'kogo do redaktora gazeti „Dilo” Dmitra Levic'kogo z viznannâm zastug pered narodom, I930, w: Mitropolit..., t. 2, к. 2).

Лист голови УНДО та Української Парламентарної Репрезентації (Дмитра Левицкого) до митр. Андрея Шептицького з проханням підтримати протестаційну акиію проти політики польських законодавчих установ стосовно украӥнського народу, 6 XII 1932, w: Митрополит..., t. 2, к. 2, s. 833-834. (List golovi UNDO ta Ukraïns'koï Parlamentarnoï Reprezentaciï (Dmitra Levic'kogo) do mitr. Andreâ Šeptic'kogo z prohannâm pidtrimati protestacjinu akcîu proti politiki pol's'kih zakonododavih ustanov stosovno ukraïns'kogo narodu, 6 XII I932, w: Mitropolit..., t. 2, к. 2).

Хомишин Г., Українська Проблема, Станиславів і933. (Homišin G., Ukraïns'ka Problema, Stanislavìv I933).

Лист митр. Андрея Шептицького до нуниія Ротти у Будапешті про стан Лвівської Apxicnapxï̈, 7 XI I94I r., w: Митрополит..., t. 2, к. 2, s. 953-954. (List mitr. Andreâ Šeptic'kogo do nunciâ Rotti u Budapešti pro stan Lvivs'koï Arhiêparhiï, 7 XI I94I r., w: Mitropolit..., t. 2, к. 2).

Мій лист до української віруючої православної інтелігенції, 3 III I942, w: Письмапослання митрополита Андрея Шептиизького з часів німеизької окупації, ч. 2, wyd. М. Гринчишин, Yorkton, Sask I969, s. 340-342. (Mij list do ukraïns'koï vìruûčoï prawoslavnoï inteligencï̈, 3 III I942, w: Pis'ma-poslannâ mitropolita Andreâ Šeptic'kogo $z$ časiv nimec'koï okupaciï, vid. M. Hrinčišin, Yorkton, Sask, 1969).

Одвертий лист української православної інтелігенції до митрополита Андрея Шептицького, kwiecień 1942 r., w: Письма..., s. 345-349. (Odvertij list ukraïns'koï prawoslavnoï inteligencï do mitropolita Andreâ Šeptic'kogo, kwiecień 1942, w: Pis'ma..., ).

Лист митр. Андрея Шептицького до проф. Володимира Кубійовича про завдання украӥнської мистецької школи у патріотичному вихованні молодi, 8 VIII 1942 r., w: Muтрополит..., t. 2, к. 2, s. 978-979. (List mitr. Andreâ Šeptic'kogo do prof. Volodimira Kubijoviča pro zavdannâ ukrä̈ns'koï mistec'kö̈ školi u patriotičnomu vihovanni molodi, 8 VIII I942, w: Mitropolit..., t. 2, к. 2).

Лист проф. Володимира Кубійовича до митр. Андрея Шептицького про мистецькой школу для вчителів рисунків, 22 VIII 1942 r., w: Митрополит..., t. 2, к. 2, s. 979-980. (List do prof. Volodimira Kubijoviča do mitropolita Andreâ Šeptic'kogo pro mistec'koï školi dlâ včitelìv risunkiv, 22 VIII 1942 r., w: Mitropolit..., t. 2, к. 2).

3 декретів собору 1942 р. Про виховання, 24 X 1942, w: Письма..., s. 23I-255. (Z dekretiv soboru 1942 r. Pro vihovannâ, 24 X I942, w: Pis'ma...,). 
Будка Н., Свящзеникам і вірним Львівської Архіспархї̈,1942, w: Письма..., s. II8-I22. (Budka N., Svâsenikam ì virnim L'vìv'koï Arhîeparhï, I942, w: Pis'ma...,).

Publikacje

Giertych J., L'eglise en Pologne Orientale. Lettre ouverte au Redacteur des «Informations catholiques internationales» a Paris, Londres 1963.

Grünberg B., Sprengel K., Trudne sąsiedztwo. Stosunki polsko-ukraińskie w X-XX wieku, Warszawa 2005.

Jagmin T., Polacy grekokatolicy na Ziemi Czerwieńskiej, Lwów 1939.

Jurkowski M., Wstę, w: Słownik ukraińsko-polski i polsko-ukraiński, cz.I: Słownik ukraińsko-polski, red. E. Hrycak, K. Kisielewski, Warszawa I990, s. XIX-XX.

Krawczuk A., Metropolita Szeptycki wobec politycznego zaangażowania kleru greckokatolickiego w Galicji, I9oo-I9I4, w: Metropolita Andrzej Szeptycki. Studia i materiaty, red. A. Zięba, Kraków I994, s. I23-I26.

Kubasik A., Arcybiskupa Andrzeja Szeptyckiego wizja ukraińskiego narodu, państwa i Cer$k w i$, Lwów-Kraków 1999.

Torzecki R., Kwestia ukraińska w Polsce w latach 1923-I929, Kraków 1989.

Андрусишин Б., Церква в українській державі I9I7-I920 рр. (доба директоріі), Київ 1977. (Andrusišin B, Cerkva v ukraïns'kì deržavi I9I7-I920 rr. (Doba direktoriï), Kï̈v I977 ).

Баран С., Митрополит Андрей Шептииький, Життя і Діяльність, München 1947. (Baran S., Mitropolit Andrej Šeptic'kij, Žittâ i Diâlnìst', München 1947).

Дзюрак Б., Виликий і небуденний Пастир, w: Митрополит..., t. I, s. XII-XLIX. (Dzûrak B., Vilikij ì nebudennij Pastir, w: Mitropolit..., t. I).

Дорошенко В., Великий митрополит (Пам'яті митрополита А. Шептиикого. Спогада i нариси), Yorktown, Sask 1958. (Dorošenko V., Velikij mitropolit (Pam'âti mitropolita A. Šeptic'kogo. Spogada ì narisi, Yorktown, Sask 1958).

Коментарі, w: Mитрополит..., t. 2, к. 2, s. I03I-I05I. (Komentari, w: Mitropolit..., t. 2, к. 2). Левицкий К., Історія політичної думки галицких українців I848-I9I4, ч. 2, Львів 927. (Levickij K., Istoriâ političnoï dumki galickih ukrä̈nciv, L’vìv 1927). 